\title{
ROLE OF SERUM FERRETIN LEVEL AS A COMPARATIVE STUDY BETWEEN NORMAL PREGNANCY AND PREMATURE RUPTURE OF MEMBRANE (PROM)
}

\author{
By
Mazen Salah Abd El-Ghaffar, Abd El-Monaem Mohammed Zakaria, Mekky Abd El-Monaem Ali and Ahmed Mohammed Saeed

Department of Obstetrics and Gynecology, Al-Azhar Faculty of Medicine, Cairo, Egypt

Corresponding author: Mazen Salah Abd El-Ghaffar,

E-mail: $\underline{\text { mazen_salah@outlook.com }}$

\begin{abstract}
Background: Preterm labor means delivery before thirty-seven completed weeks of gestational age of pregnancy. Premature rupture of membranes occurs in three percent of pregnancies and considered the main cause of one third of preterm deliveries.

Objective: To determine whether serum ferritin levels could be used as a predictive marker of premature rupture of membranes or not.

Patient and Methods: Descriptive prospective comparative study started from September 2019 till March 2020. This study was conducted on pregnant females (30-37 weeks). Serum ferritin was high among group I when compared with group II. One hundred healthy pregnant women were enrolled in this study and full field the following criteria from September 2019 till March 2020 at Al- Hussein University Hospital.

Results: The results were tabulated and statistically analyzed by suitable statistical methods after completion of the study. And it shows highly statistically significant increase in gestational age in intact membrane group compared to PROM group and statistically significant increase in serum ferretin in PROM group compared ti intact membrane group. Also there was an inverse correlation between serum ferretin and gestational age while there is a direct correlation between serum ferretin and hematocrit value. There is a non-significant difference between both groups according to maternal age, hemoglobin or hematocrit.
\end{abstract}

Conclusion: Serum ferritin is a marker for preterm premature rupture of membranes, and could be used to expect complications by obstetricians, and it considered more specific for prediction.

Keywords: Preterm labor, Ferritin, Rupture of membrane.

\section{INTRODUCTION}

Preterm premature rupture of membranes (PPROM) means spontaneous rupture of fetal membranes before 37 completed weeks and before the onset of labor (Cunningham et al., 2014). The etiology of PROM is multifactorial. Maternal enzymes, maturational and mechanical forces, phospholipids content, collagen disruption, amniotic-cell cytokines induced by fetal signals and bacterial phospholipases and collagenases all play major and interrelated role (Chen et al., 2014).

Maternal complications of PROM occurred such as infection, preterm 
labour, abruptio-placentae and increased cesarean section rate. The severity and frequency of associated neonatal complications increases when the gestational age at diagnosis decreases. Respiratory distress syndrome is the most common serious complication observed in babies after a pregnancy complicated by PPROM (American College of Obstetrics and Gynecology, 2013).

Other foetal and neonatal complications include fetal/ neonatal infection, respiratory disorders such as pulmonary hemorrhage, bronchopulmonary dysplasia, chronic lung disease, perinatal asphyxia, fetal distress and patent ductus arteriosus. Neurological complications include intraventricular hemorrhage, cerebral palsy and periventricular leukomalacia. Cord compression is a major complication when severe oligohydramnios exists and cord prolapse which is a common complication of preterm delivery due to failure of engagement of the presenting part. Amniotic band syndrome may lead to formation of bands or strings of amnion that adhere to the foetus and impair growth and development of the involved structure.

The management of patients with PROM, regardless of gestational age, remains controversial. Treatment depending on gestational age and includes consideration of delivery when rupture of membranes occurs at or after 34 weeks' gestation. Corticosteroids decreases neonatal complications, especially respiratory distress syndrome and intraventricular hemorrhage and antibiotics are effective for increasing the latency period (Liu et al., 2010).
The role of tocolytic therapy and cervical cerclage remain controversial. Ferritin is a major iron storage protein found not only in spleen, liver and bone marrow, but also in mucosal cells of small intestine, in placenta, kidney, testes, skeletal muscle, and in circulating plasma. It is difficult to define the origin of circulating ferritin (Bouchghoul et al., 2019).

The major function of ferritin is clearly to provide a store of iron which may be used for haem synthesis when required (Jankowska et al., 2013). Measurement of serum ferritin is the most sensitive indicator of body iron stores in a normal healthy adult (Daru et al., 2017). Ferritin may have immune modulatory activities. Several studies have indicated that ferritin can modulate the immune function in humans by inhibiting lymphocyte function, by inhibiting delayed type hypersensitivity response and by inducing myelosuppression. Thus, it is possible that the chronic high serum ferritin levels caused some immunosuppression (Wang et al., 2010).

Ferritin is an acute phase reactant as it increases during inflammation. The high level of ferritin is most likely a part of acute phase reaction to subclinical genital tract infection or inflammation. It can be used as a marker for PPROM and may help the physicians to anticipate it (Valappil et al., 2015).

So, the aim of our study was to determine the effect of serum ferritin levels in prediction of preterm premature rupture of membranes. 


\section{PATIENTS AND METHODS}

\section{Study Design:}

Descriptive prospective comparative study started from September 2019 till March 2020.

\section{Ethical Consideration:}

1. Study protocol was submitted for approval by Institution Research Board (IRB) of Faculty of Medicine AL Azhar University Cairo.

2. Informed consent of the hospital authorities.

3. Informed verbal consent was obtained from each participant sharing in the study.

4. Confidentiality and personal privacy were respected in all levels of the study. Collected data were not be used for any other purpose.

\section{Study population:}

One hundred healthy pregnant women were enrolled in this study and full field the following criteria from September 2019 till March 2020 at Al- Hussein University Hospital.

\section{Inclusion criteria:}

1. Pregnant women aged 20-35 years.

2. Pregnant with rupture of membrane.

3. Hemoglobin ( $\mathrm{Hb})$ levels were $\geq 10.0 \mathrm{gm} / \mathrm{dl}$.

\section{Exclusion Criteria:}

1. Women with induced labor.

2. Mal-presentations (breech, face).

3. Multiple pregnancies.

4. Medical disorders like severe anemia (hemoglobin $<7 \mathrm{~g} / \mathrm{dl}$ ), gestational hypertension, pre-eclampsia and diabetes mellitus.

All subjects were have undergone: Complete medical history, physical examination, speculum examination and laboratory investigations (complete blood picture and serum ferretin).

Patients in this study were presented with rupture of membrane. Hemoglobin $(\mathrm{Hb})$, hematocrit (Hct) level and serum ferretin were estimated before the delivery. Maternal pulse and blood pressure were recorded immediately after delivery.

Outcome Measures: Elevation of serum ferritin level.

\section{Statistical analysis:}

Recorded data were analyzed using the statistical package for the social sciences, version 20.0 (SPSS Inc., Chicago, Illinois, USA). Quantitative data were expressed as mean \pm standard deviation (SD). Qualitative data were expressed as frequency and percentage. MannWhitney, U test was for comparison Pvalue $<0.05$ was considered significant.

\section{RESULTS}

The present study included 100 women. Group 1 (50 with PPROM) and group 2 (50 with intact membranes). Our results showed no statistically significant difference between groups according to age (years). While the results showed highly statistically significant increase GA (wks) in intact membrane group compared 
to PROM group. The study showed statistically significant difference between groups according to multi para and Prev. I. The hemoglobin level was nearly comparable with non-statistical significant difference between studied groups. The serum ferritin level was high among PROM group with statistically significant difference compared to intact membrane group (Table 1).

Table (1): Comparison between PROM group and intact membrane group according to age, gestational age, parity, hemoglobin and serum ferritin level

\begin{tabular}{|l|c|c|c|}
\hline & $\begin{array}{c}\text { PROM group } \\
(\mathbf{n = 5 0 )}\end{array}$ & $\begin{array}{c}\text { Intact } \\
\text { membrane } \\
\text { group (n=50) }\end{array}$ & p-value \\
\hline $\begin{array}{l}\text { Age (years): } \\
\text { Mean } \pm \text { SD } \\
\text { Range }\end{array}$ & $\begin{array}{c}26.70 \pm 4.54 \\
20-35\end{array}$ & $\begin{array}{c}27.27 \pm 5.53 \\
20-35\end{array}$ & $<0.001^{* *}$ \\
\hline $\begin{array}{l}\text { Gestational age (wks.): } \\
\text { Mean } \pm \text { SD } \\
\text { Range }\end{array}$ & $\begin{array}{c}36.00 \pm 0.57 \\
35-37\end{array}$ & $\begin{array}{c}38.36 \pm 1.03 \\
37-40\end{array}$ & $<0.001^{* *}$ \\
\hline Parity, O/H: & & & \\
\hline PG & $6(12.0 \%)$ & $10(20.0 \%)$ & 0.413 \\
\hline Multi Para & $30(60.0 \%)$ & $40(80.0 \%)$ & $0.049^{*}$ \\
\hline Prev1 CS & $8(16.0 \%)$ & $0(0.0 \%)$ & $0.006^{*}$ \\
\hline Prev2 CS & $2(4.0 \%)$ & $0(0.0 \%)$ & 0.495 \\
\hline Prev3 CS & $4(8.0 \%)$ & $0(0.0 \%)$ & 0.117 \\
\hline Hemoglobin: & $11.78 \pm 0.70$ & $11.74 \pm 0.86$ & 0.799 \\
Mean \pm SD & $10-12.5$ & $10-12.7$ & \\
Range & $44.20 \pm 17.39$ & $34.28 \pm 14.58$ & $0.018^{*}$ \\
\hline $\begin{array}{l}\text { Serum ferritin level: } \\
\text { Mean } \pm \text { SD } \\
\text { Range }\end{array}$ & $8-98$ & $9-73$ & \\
\hline
\end{tabular}

\section{DISCUSSION}

In the present study, there were nostatistically significant differences between the two groups regarding maternal age. These results agree with Kim et al. (2011) and Palatnik and Grobman (2015) who reported that the mean age were not different between the study and the control group. Yael et al. (2015) has noticed that maternal age had no significant difference of prediction of PPROM.

In contradiction, Greco et al. (2011) noticed that the risk for spontaneous early PPROM increases with maternal age.
Older women are at greater risk of preterm birth and still birth (Lisonkova et al., 2010). Studies carried out in UK, France and USA showed that grand multiparity and nulliparity were associated with increased rate of preterm labor (Manzoor et al., 2015).

The study concluded that young adolescents, and especially those of low gynecologic age, appeared prone to PTL and these findings suggested that it was the biological immaturity often associated with young age, rather than young maternal age per se. Musilova et al. (2017) stated that maternal age alone 
cannot be used as a predictor for early PTL and PPROM.

The present study showed a statistically significant difference between the two groups according to multi parity and previous cesarean section. This was with agreement with Fernandes and Chandra (2015) who reported that the risk of preterm labor increased with parity. Kim et al. (2011) reported that parity was not associated with significantly difference between study and control group.

Our study showed a highly statistically significant increase GA (wks.) in intact membrane group compared to PROM group.

The hemoglobin level was nearly comparable with non-statistical significant difference between the studied groups It was observed that anemic women have high incidence/risk of preterm delivery at the time of delivery than non-anemic. No other difference in neonatal outcome was observed (Manzoor et al., 2015). On the other hand, Omar et al. (2019) studied the hematological values included hemoglobin level, serum iron and serum ferritin. They found that only the determination of serum ferritin is of particular relevance as a significant correlation and ascertained between low serum ferritin levels and the incidence of preterm labor.

Our study showed no statistically significant difference between both groups according to HCT although Khoigani et al. (2012) has reported that about 2.35 percent of participants affected with preterm premature rupture of membranes and the average hemoglobin in the first and average hematocrit in the second half did not differ in both groups. However, the average hemoglobin in the second half of pregnancy of the group who later developed preterm premature rupture of membranes was significantly lower than others.

In the present study, serum ferritin level was high among preterm premature rupture of membrane when compared with control group with statistically significant differences. These results agreed with Nandini et al. (2015) who showed that serum ferritin levels were significantly higher in preterm labor. The best and most effective prevention of preterm delivery incidence is early identification of pregnant women who belong to a group of high risk (Nandini et al., 2015).

Our study came in agreement with the study of Valappil et al. (2015) who showed that serum ferritin was significantly elevates in PPROM cases when compared to the control group of women with same gestational period. Faucett et al. (2016) suggested that higher plasma ferritin levels may serve as a marker of infection among women with premature rupture of membrane.

The high values in the serum ferritin levels in the PPROM cases could be due to infection associated with PPROM. The inflammatory response that leads to membrane weakening is currently being defined. A number of studies have been done to ascertain the incidence of infection induced PPROM (Mendz et al. 2013 and Cunningham et al., 2014).

In pregnancy, there was a change in vaginal $\mathrm{pH}$ which may result in vagino cervical infection. This followed bacterial colonization and macrophage infiltration at the chorion decidual interface and 
ferritin is produced as part of acute phase response (Mendz et al., 2013). Brailsford et al., (2013) proposed that the increased extracellular ferritin has an important role in host defense against bacteremia by stimulating oxidative metabolism.

The high serum ferritin level in the PPROM group is thus most likely a part of 'acute phase reaction' to a subclinical genital infection or inflammation. So, serum ferritin may be used a marker of PPROM cases and may help the physicians to anticipate it (Valappil et al., 2015).

Pregnancy predispose to vaginocervical infection due to altered vaginal $\mathrm{pH}$. The chorion-decidual interface is infiltrated by macrophages following bacterial colonization and ferritin is produced as an acute phase reactant (Wei et al., 2010). A study done by Movahedi et al. (2012) noticed significantly high levels of serum ferritin in patients who had preterm delivery. It seems that elevated mid-pregnancy serum ferritin levels can be predictive of spontaneous preterm delivery, especially those occurring at early gestational ages.

Some mechanisms have been suggested for these evidences. First, the presence of increased levels of ferritin might reflect an acute phase reaction to subclinical genital tract infection or inflammation (Movahedi et al., 2012). In addition, it may be also explained by the covert process of infection associated with preterm delivery that causes tissue damage resulting in increased serum ferritin levels that act as an acute phase reactant (Wang et al., 2010).

\section{CONCLUSION}

Elevated serum ferritin level was predictive of early spontaneous preterm premature rupture of membrane because it reflects an acute- phase reaction to subclinical infections. Serum ferritin was significantly elevated in preterm premature rupture of membranes when compared to the control group of women with same gestational period. Serum ferritin acted as a marker for preterm premature rupture of membranes, and could be used by obstetricians to expect complications, and it considered more specific for prediction.

\section{REFERENCES}

1. American College of Obstetrics and Gynecology (2013): Premature rupture of membranes. ACOG Practice bulletin No. 139. Obstet Gynecol., 122:918-30.

2. Bouchghoul H, Kayem G, Schmitz T, Benachi A, Sentilhes L, Dussaux $C$ and Senat MV (2019): Outpatient versus inpatient care for preterm premature rupture of membranes before 34 weeks of gestation. Scientific Reports, 9(1):1-8.

3. Brailsford S,Lunec J,Winyard $P$ and Blake DR (2013): A possible rule for ferretin during inflammation. Free Radic RES Commun, 1(2):101-09.

4. Chen LM, Du WJ, Dai J, Zhang Q, Si GX, Yang H, Ye EL, Chen QS, Yu LC, Zhang C and Lu XM (2014): Effects of subclinical hypothyroidism on maternal and perinatal outcomes during pregnancy: a single-center cohort study of a Chinese population. PloS One, 9(10):e109364.

5. Cunningham FG, Leveno KJ, Bloom SL, Spong CY, Dashe JS, Hoffman BL, Casey BM and Sheffield JS (2014): (Editors), Abnormal labor, In Williams Obstetrics, $24^{\text {th }}$ edition, section 6 , chapter 
23; 455-476 \&pp 838-39, Pbl. McGrawHill Education.

6. Daru J, Colman K, Stanworth SJ, De La Salle B, Wood EM and Pasricha SR (2017): Serum ferritin as an indicator of iron status: what do we need to know? The American Journal of Clinical Nutrition, 106(6):1634-1639.

7. Faucett AM, Metz TD, DeWitt PE and Gibbs RS (2016): Effect of obesity on neonatal outcomes in pregnancies with preterm premature rupture of membranes. American Journal of Obstetrics and Gynecology, 214 (2):287-288.

8. Fernandes $S$ and Chandra $S$ (2015): A study of risk factors for preterm labor. Int J Reprod Contracept Obstet Gynecol., 4(5):1306-1312.

9. Greco E, Gupta R, Syngelaki A, Poon LC and Nicolaides KH (2011): Firsttrimester screening for spontaneous preterm delivery with maternal characteristics and cervical length. Fetal Diagnosis and Therapy, 31 (3): 154-161.

10. Jankowska EA, Von Haehling $S$, Anker SD, Macdougall IC and Ponikowski P (2013): Iron deficiency and heart failure: diagnostic dilemmas and therapeutic perspectives. European Heart Journal, 34(11):816-29.

11. Khoigani MG, Goli $S$ and HasanZadeh A (2012): The relationship of hemoglobin and hematocrit in the first and second half of pregnancy with pregnancy outcome. Iranian Journal of Nursing and Midwifery Research, 17(2): 165-171.

12. Kim AM, Lee BS, Yong-Won $P$ and Kyung $S$ (2011): Serum markers for prediction of spontaneous preterm delivery in preterm labour. European Journal of Clinical Investigation, 41 (7): 773-780.
13. Lisonkova S, Janseen PA, Sheps SB, Lee SK and Dahlgram L. (2010): Effects of maternal age on adverse birth outcomes: dose party matters. J Obstet Gynaecol Can., 32(6):541-548.

14. Liu J, Feng ZC and Wu J (2010): The incidence rate of premature rupture of membranes and its influence on fetalneonatal health: A Report from Mainland China. Journal of Tropical Pediatrics, 56(1):36-42.

15. Manzoor $S$, Maleeha $M$ and Madiha $M$ (2015): Maternal anemia as a risk factor for preterm labor. Merit Research Journal of Medicine and Medical Sciences, 3(10): 472-475.

16. Mendz GL, Kaakoush NO and Quinlivan JA (2013): Bacterial aetiological agents of intra-amniotic infections and preterm birth in pregnant women. Frontiers in Cellular and Infection Microbiology, 3:58-61.

17. Movahedi M, Saiedi M, Gharipour M and Aghadavoudi $O$ (2012): Diagnostic performance and discriminative value of the serum ferritin level for predicting preterm labor. Journal of Research in Medical Sciences: the official journal of Isfahan University of Medical Sciences, 17(2):164-169.

18. Musilova I, Pliskova L, Gerychova R, Janku P, Simetka O, Matlak P, Jacobsson $B$ and Kacerovsky $M$ (2017): Maternal white blood cell count cannot identify the presence of microbial invasion of the amniotic cavity or intraamniotic inflammation in women with preterm prelabor rupture of membranes. PloS One, 12(12):e0189394.

19. Nandini M, Shetty HV, Rupakala BV, Usha SM, Priyadarshini KS, Manjula HS and Victoria K (2015): Study of serum ferritin levels in preterm labor. International Journal of Recent Trends in 
Science and Technology, 14 (2): 477480.

20. Omar KA, Ayad WA and El-Sayed MR (2019): Serum Ferritin as a Marker for Preterm Premature Rupture of Membranes. Parity, 28(31):29-31.

21. Palatnik A and Grobman WA (2015): The relationship between first-trimester subchorionic hematoma, cervical length, and preterm birth. Am J Obstet Gynecol., 213(3):403-407.

22. Valappil SA, Varkey M, Areeckal B and Thankan $K$ (2015): Serum ferritin as a marker for preterm premature rupture of membranes-a study from a tertiary centre in central Kerala. Journal of Clinical and Diagnostic Research: JCDR, 9(7):9-12.
23. Wang W, Knovich MA, Coffman LG, Torti FM and Torti SV (2010): Serum ferritin: past, present and future. Biochimica et Biophysica Acta (BBA)General Subjects, 1800(8):760-769.

24. Wei SQ, Fraser W and Luo ZC (2010): Inflammatory cytokines and spontaneous preterm birth in asymptomatic women: a systematic review. Obstetrics \& Gynecology, 116(2):393-401.

25. Yael ST, Alon $S$ and Richard NB (2015): Prolonged Second Stage of Labor and the Risk for Subsequent Preterm Birth. J Obstet Gynaecol Can., 37(4): 324-329. 


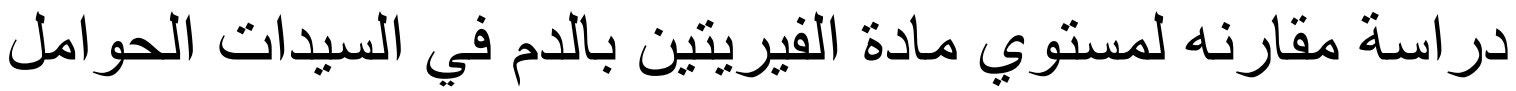 لحالات الولادة الطبيعية وحالات الانفجار الإن المبكر للكيس

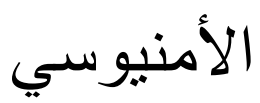

مسازن صالح عبد الغفـار, عبد المنعم محمد زكريا, مكي عبد المنعم علىث، أحمد محمد الائ

\section{سعيد}

قسمى التوليد وامراض النساء والباتولوجيا الأكلينيكية*، كلية الطب، جامعة الأزهر

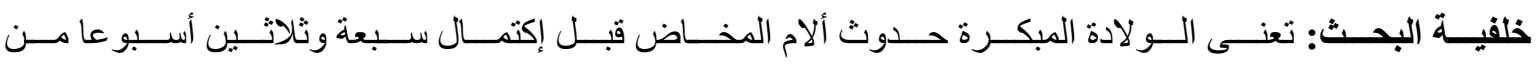

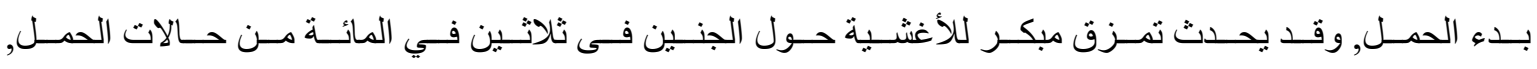

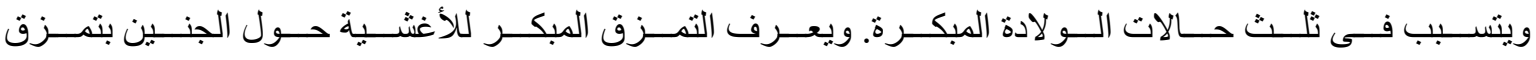
الأغشية قبل اكتمال سبعة وثلاثين أسبو عا من الحمل وقبل حدوث الإم الو لادة.

الهـف من البحث: تحديد تأثير مستوى الفيريتين كأحد أسباب توقع التمزق المبكر لجيب المياه.

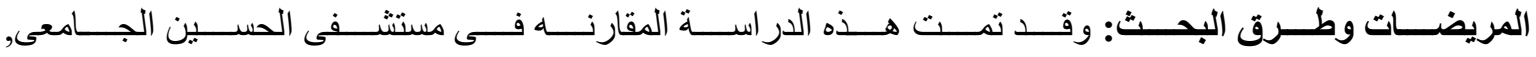

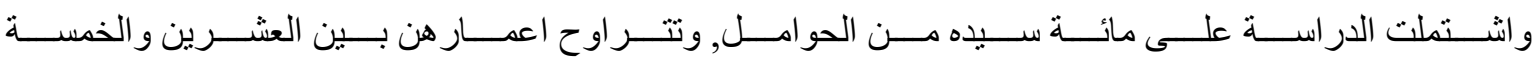

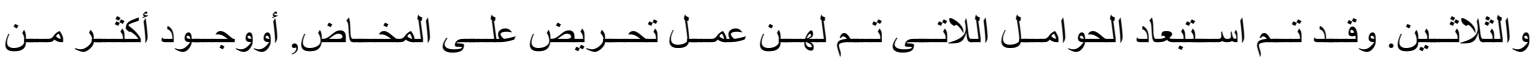

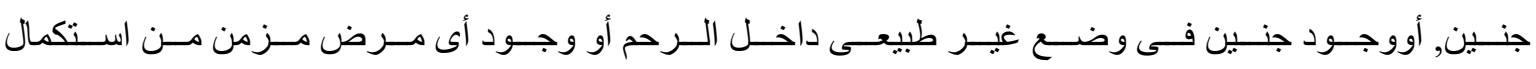

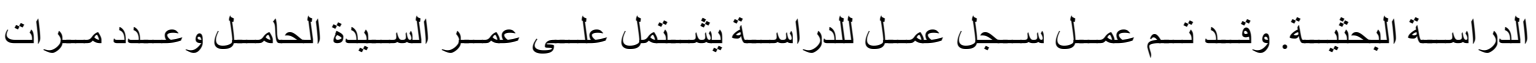

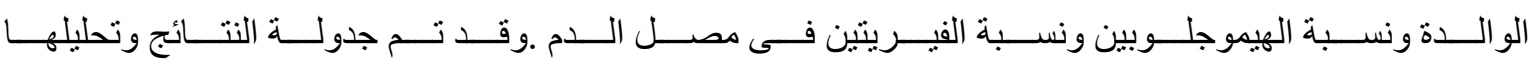
إحصائيا بالطرق الحصائية المناسبة بعد اكتمال الدراسة.

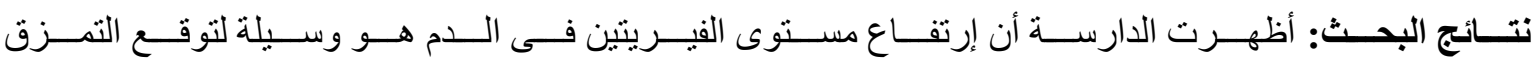

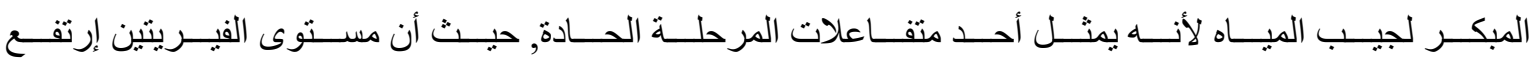

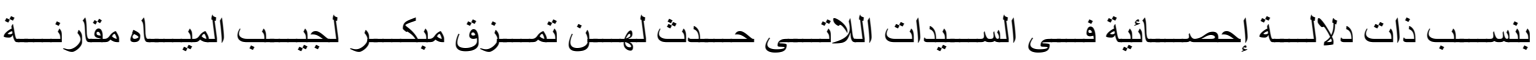
بالسيدات الحوامل لنفس فترة الحمل ولم يحدث لهن تمزق مبكر لجيب المياه.

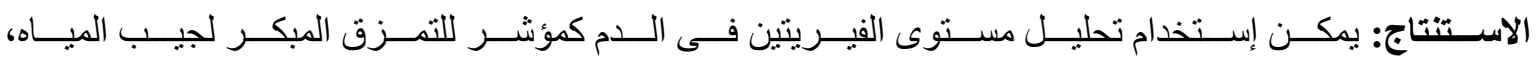
وقد يساعد فى معرفة هذه المضاعفات وتوقعها قبل حدوثها. 